\title{
A BOUND TESTING ANALYSIS OF BANK CREDIT SUPPLY DETERMINANTS IN NIGERIA
}

\section{Adebowale M. Adeleke, Olabanji B. Awodumi}

(1) Department of Economics, University of Ibadan, Ibadan, Oyo state, Nigeria

(2) Department of Economics, University of Ibadan, Ibadan, Oyo state, Nigeria

\author{
Adebowale M. Adeleke \\ Department of Economics, \\ University of Ibadan, Ibadan, Oyo state, Nigeria \\ adelekemusefiu@gmail.com \\ Article info \\ Paper category: Original Scientific Paper \\ Received: 21.1.2018. \\ Accepted: 6.3.2018. \\ JEL classification: $\mathrm{G}_{21}, \mathrm{E}_{44}, \mathrm{C}_{1} 3, \mathrm{C}_{22}, \mathrm{E}_{51}$
}

Keywords

Bank Credit Supply; ARDL; Nigeria 


\begin{abstract}
Purpose. Attention of macroeconomists and financial experts has focused on the determinants of bank credit, with more attention on the demand side analysis. However, few existing study on the supply side determinants of bank credit are reported with inconsistent results, though they emphasized the role of economic growth. By employing Autoregressive Distribution Lag estimation technique, this study specifically focuses on the short-run dynamic and long-run effects of bank credit supply determinants in Nigeria using the data that span 1970-2015. We found that exchange rate, money supply, net foreign liabilities and real GDP all have a positive long-run impact on bank credit to private sector in Nigeria, whereas the effect of the general price level is negative. In the short run, the effect of money supply, net foreign liabilities and reserve requirement on bank credit to the private sector is positive with only inflation exerting a negative influence. In conclusion, policymakers are required to implement policies that stabilize the financial system and boost per capita income in order to promote a sustained and stable growth of bank credit to private sector in Nigeria. Bankers also should, however, monitor the rate at which they create credit which has implication for the overall money supply. The study was set out to estimate both the short and long-run relationship as well as dynamic effect of supply side factors on bank credit to private sector in Nigeria between 1970 and 2015.
\end{abstract}

Methodology. The study employed Linear Autoregressive Distributed Lag (ARDL) co-integration test as suggested by Pesaran, Shin and Smith, (2001).

Findings. It was evidenced that exchange rate, money supply, net foreign liabilities and real GDP all have a positive long-run impact on bank credit to private sector in Nigeria, whereas the effect of the general price level is negative. In the short run, the effect of money supply, net foreign liabilities and reserve requirement on bank credit to the private sector is positive with only inflation exerting a negative influence.

Limitations. This study is limited only by its focus on the supply size analysis. A new line of study is suggested that can possibly investigate both the demand and supply size analysis together in one paper.

Originality. This is an original work and has neither been published in any other peer-reviewed journal nor is under consideration for publication by any other journal. 


\section{INTRODUCTION}

Globally, the importance of financial system is critical to the functioning of an economy as a whole and financial institutions such as banks are central to the financial system. In the literature of finance, aside the provision of employment, finance also serves three main purposes, which are credit provision, liquidity provision and risk management services that allow businesses and households to pool their risks from exposures to financial market and commodity price risks. Much of this is provided by banks through derivatives transactions. The supply of high powered money from the central bank forms the basis of the overall money supply in an economy (Blanchard, 2005). The supply of bank credit, especially for business investment, therefore primarily depends on the amount of monetary base at any given period of time. Central banks influence bank credit, as well as overall money supply, through the use of a numbers of instruments including discount rate and reserve requirement which have implication for the cost of borrowing.

Mild monetary conditions and healthy banking sector enhance credit creation while financial market imperfections generate borrowing constraints, hence lower credit as well as economic growth (Imran and Nishat, 2013). Apart from the monetary factors, the ability of Deposit Money Banks (DMBs) to lend funds to business firms is limited by economic atmosphere. Since commercial banks are also in business to maximize the returns to their shareholders, their lending behaviour largely considers economic situations. During recession, business activities are on the downturn and banks find it more risky to lend to businesses as default rate tends to increase while rising prices signal opportunities for firms to increase the prices of their products and make higher profits in the process. However, rising prices is an indication of economic instability and may suggest increasing cost of input, which could affect business growth while banks may be reluctant to lend funds for investment in such economic situation. In addition, an economy's engagement in foreign activities is mainly financed through bank credit. Hence, banks monitor exchange rate movement and other foreign activities of an economy in order to lend funds to the most profitable activities. Thus, a strong financial system is an essential catalyst for economic growth and development while the performance of an economy is important for the functioning of the financial system. This two-way process has implication for credit growth.

Bank lending channel is important channel through which government monetary policies transmit into real economic activities. Given the nature of small scale firms, which dominate business activities in Nigeria, they are not listed on the stock exchange and cannot raise funds through shares and therefore rely on bank credit. The amount of bank credit available influences the interest rate which has implication for individual savers and investors as well as banks who have the task of deciding which of the alternatives is worthy of the available funds. 
In Nigeria, Deposit Money Banks (DMBs) are major players in funds mobilizing. Intuitively, DBMs help mobilized resources from the surplus segments of the economy to the deficit sectors; thus ensuring a more dexterous resource distribution and utilization. Domestic credit provided to private sector in the country remained unstable for most of the periods 1970-2015. Prior to the introduction of universal banking system in Nigeria in year 2001; which allow DMBs to choose the segment of the financial market they wish to operate, commercial banks are at the retail end of the market where the small and medium savings are mobilized and disbursed in form of loans, purchases of non-equity securities and trade credits provisions to firms and corporations for financing their operations.

However, though the nature of the bond for bank credit determinants has been empirically debated overtime, but there is no consensus. In the literature, two major strands are prominent about the drivers of bank credit in an attempt to enhance the financing of business operations on the part of firms and corporations - the demand and the supply side approach. Studies such as Qayyum, 2002; Khawaja and Din, 2007; Awan, 2009; Afzal and Mirza, 2010; Ali, Akhtar, and Ahmed, 2011; Sharma and Gounder, 2012; Tan, 2012; Ewert, 2000; Akinleye, 2012; Asekome and Agbonkhese, 2014, and Emecheta and Ibe, 2014, among others, focus on the demand side analysis of bank credit using different countries and econometrics techniques.

The few existing empirical studies on the supply side determinants of bank credit (Guo and Stepanyan, 2011; Olokoyo, (2011); Imran and Nishat, 2013 and Assefa, 2014) reported inconsistent results, though they emphasized the role of economic growth. To the best of our knowledge, such empirical analysis is limited to Olokoyo, (2011) in Nigeria which utilized data covering the period 1980-2005. Given recent developments in the financial sector in Nigeria including the introduction of cashless policy, there is need for new empirical evidence that captures the dynamics in the economy. Therefore, this study seeks to estimate both the short and long-run relationships as well as dynamic effect of supply side factors on bank credit to private sector in Nigeria between 1970 and 2015. Interestingly, it is observed that there is no such study that captures the relevant supply side variables in the same framework for the Nigeria. Understanding the nature of the bond among these supply side factors, has a great implication for policy-makers' decision about the appropriate strategies and policies to adopt towards making financial resources such as loans, purchases of non-equity securities, trade credits and other accounts receivables available to support the private sector of the economy. Therefore, this present study identifies the supply side factors that influence bank credit allocation to business firms in Nigeria.

Pertinent to the above, this current study improves on previous studies by estimating the Autoregressive Distributed Lag (ARDL) co-integration test popularly known as the bound test and error correction model (ECM) to shows the long-run 
relationships and dynamic interactions of foreign liabilities, growth, interest rate spread and its determinants. Following the introductory section, the rest of the paper is organized into five sections as follows: the next section, section two provides brief stylized facts on Nigerian Bank credit. This is followed by section three, where detailed literature review was examined. Section four detailed the econometric methodology and data sources for the study. Section five entails the results and discussions of findings, section six, the last section, focuses on the conclusion and policy implications of the study.

\section{STYLIZED FACTS ON NIGERIA BANK CREDIT}

Globally, financial institutions help in the mobilization and distribution of funds in form of loans, purchases of non-equity securities and trade credits provisions to firms and corporations. These funds are later utilised by the corporate organisations for financing and expanding their business operations. In Nigeria, following the deregulation of interest rate in the post 1986 Structural Adjustment Programme (SAP) era, the spread between deposit and lending rate began to widen and thus, interest rate spread increased remarkably. Moreover, the increasing divergence between the lending rate and the deposit rate, otherwise known as the interest rate spread measures distortions in the money market. This interest rate spread, along with some other macroeconomic variables, is depicted in Table 1. On a five years average, between 1970 and 1974, the interest rate spread was $3.84 \%$, rising to a value of $7.14 \%$ and $6.69 \%$ during the periods $2000-2004$ and $2005^{-2009}$ respectively. Recently, the value of the interest rate spread stood at $8.77 \%$ in 2015 . These high interest rate spread periods infer that cost of borrowing has gone up in the organised financial market, thereby increasing the cost of operations in Nigeria. However, domestic credit to private sector spread rose from $5.44 \%$ in $1970-1974$ period to $15.79 \%$ in $1980-1984$ and a peak of $24.76 \%$ in 2005-2009. The spread in domestic credit to private sector has since increased on yearly bases and stood at $13.37 \%$ in 2015 , following a series of up and down turns.

On a yearly trend, domestic credit to private sector began with a value of $4.92 \%$ in 1970 and rose to about $12.23 \%$ in 1980 . By 1990, the figure sharply dropped to $8.7_{1} \%$ and continuously fluctuated since then. In year 2000 , the figure stood at approximately $12.35 \%$, and by 2010 and 2015 , the figure had climbed up to $15.42 \%$ and $13.37 \%$ respectively on approximation. This implies more credit access to firms and corporations. The country credit provision to firms and corporations was measured at $11.80 \%$ in 2012. A critical look at Figure 1 . shows that credit to private sector $(\%$ of GDP) was low and not stable initially, before picking up gradually in the later years. The best performance in the country was recorded in 2008 and 2009 respectively with a credit value of $33.75 \%$ and $38.39 \%$ of GDP. 
Figure 1.: Trends of domestic credit to private sector in Nigeria (\% of GDP)

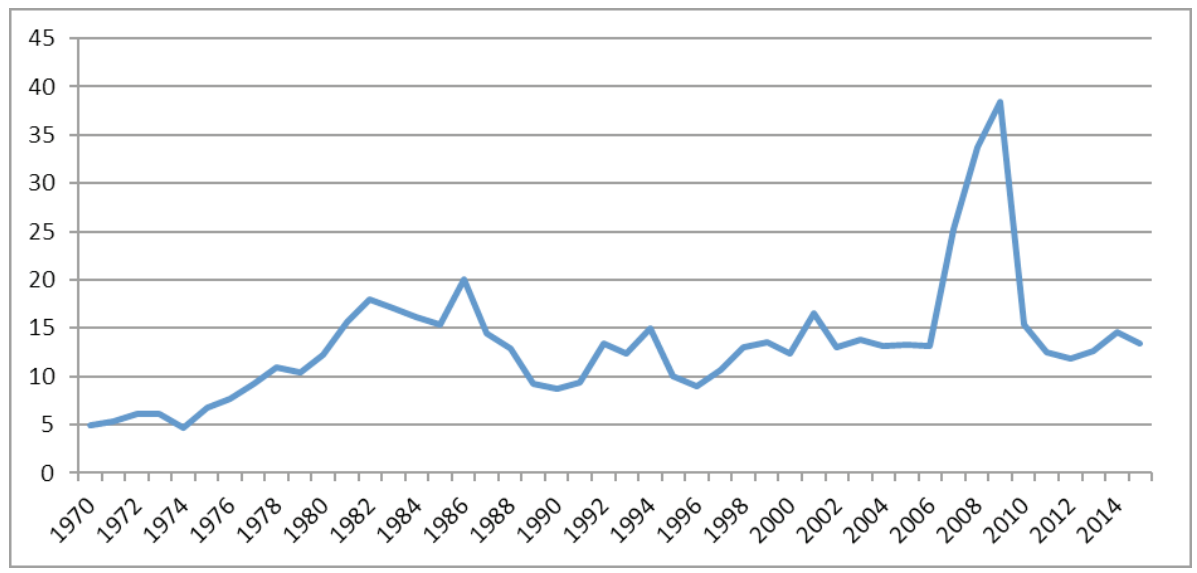

Source: Author, underlying data obtained from the WDI, 2015 and 2016 online version.

Per capita GDP per capita which stood at about \$694.49 in 1970 and $\$ 840.54$ in 1980 and averaged $\$ 695.21$ between 1980 and 1984, increased, on a five years average, to $\$ 878.85$ during $2005^{-2009}$ fiscal periods and recorded an annual value of $\$ 1041.33$ in 2015. A critical examination of Table 1 . further showed that inflation and consumer prices (annual \%) in the country has consistently maintained a double digit rate on a five years average, except between 2010 and 2014. Inflation trend has relatively been on the low side in the earlier period. However, it recorded its worst performance of $4.8 .93 \%$, on five years average, between in 1990 and 1994 falling to $14.99 \%$ in 2003 and $9.72 \%$ in 2015 .

Table 1.: Trends in major macroeconomic indicators in Nigeria from 1970 to 2015

\begin{tabular}{|c|c|c|c|c|c|c|c|c|}
\hline Year & $\begin{array}{c}\text { Do- }^{-} \\
\text {mestic } \\
\text { credit } \\
\text { to pri- } \\
\text { vate } \\
\text { sector } \\
\text { (\% of } \\
\text { GDP) }\end{array}$ & $\begin{array}{c}\text { Nigeria's } \\
\text { external } \\
\text { debt out- } \\
\text { standing }^{-} \\
\text {(N' Bil- } \\
\text { lion) }\end{array}$ & $\begin{array}{c}\text { Infla- } \\
\text { tion, } \\
\text { con- } \\
\text { sumer } \\
\text { prices } \\
\text { (annual } \\
\%)\end{array}$ & $\begin{array}{c}\text { Official } \\
\text { ex- } \\
\text { change } \\
\text { rate } \\
\text { (LCU } \\
\text { per } \\
\text { US\$, } \\
\text { period } \\
\text { aver- } \\
\text { age) }\end{array}$ & $\begin{array}{l}\text { Money } \\
\text { and } \\
\text { quasi } \\
\text { money } \\
\left(\mathrm{M}_{2}\right) \\
\text { as \% of } \\
\text { GDP }\end{array}$ & $\begin{array}{c}\text { Inter- } \\
\text { est rate } \\
\text { spread }^{1} \\
(\%)\end{array}$ & $\begin{array}{c}\text { Total } \\
\text { re- } \\
\text { serves }^{2} \\
\text { (in- } \\
\text { cludes } \\
\text { gold, } \\
\text { current } \\
\text { US\$) }\end{array}$ & $\begin{array}{l}\text { GDP per } \\
\text { capita } \\
\text { (con- } \\
\text { stant } \\
2005 \\
\text { US\$) }\end{array}$ \\
\hline $1970-1974$ & $5 \cdot 44$ & $24,3.68$ & 14.30 & 0.67 & 11.26 & 3.84 & 1.48 & $7^{8} 5 \cdot 7^{3}$ \\
\hline $1975-1979$ & 9.01 & 790.64 & $16.5^{6}$ & 0.63 & 20.84 & 3.22 & 4.64 & 832.66 \\
\hline $1980-1984$ & $15 \cdot 79$ & $7680.7^{6}$ & 15.40 & 0.67 & 31.01 & 2.00 & $3.9^{3}$ & 695.21 \\
\hline $1985-1989$ & $14.42^{2}$ & $10677^{8.42}$ & 25.87 & $3.7^{1}$ & 26.75 & 3.31 & 1.54 & $55^{1.39}$ \\
\hline $1990-1994$ & $11.7^{8}$ & 490657.94 & $48.9^{3}$ & 15.86 & 24.74 & 6.87 & 2.66 & $5^{6} 5.5^{\circ}$ \\
\hline $1995-1999$ & 11.25 & $1028101.7^{8}$ & 12.27 & $35.9^{8}$ & $16.7^{3}$ & $8.5^{1}$ & 5.35 & $542 \cdot 7^{3}$ \\
\hline $2000-2004$ & $13.7^{8}$ & $3915 \circ 31.72$ & $15.7^{3}$ & 119.12 & 21.78 & 7.14 & 10.60 & 618.68 \\
\hline
\end{tabular}




\begin{tabular}{|c|c|c|c|c|c|c|c|c|}
\hline Year & $\begin{array}{c}\text { Do- }^{-} \\
\text {mestic } \\
\text { credit } \\
\text { to pri- } \\
\text { vate } \\
\text { sector } \\
(\% \text { of } \\
\text { GDP) }\end{array}$ & $\begin{array}{c}\text { Nigeria's } \\
\text { external } \\
\text { debt out- } \\
\text { standing } \\
\text { (N' Bil-- } \\
\text { lion) }\end{array}$ & $\begin{array}{c}\text { Infla- } \\
\text { tion, } \\
\text { con- } \\
\text { sumer } \\
\text { prices } \\
\text { (annual } \\
\%)\end{array}$ & $\begin{array}{c}\text { Official } \\
\text { ex- } \\
\text { change } \\
\text { rate } \\
\text { (LCU } \\
\text { per } \\
\text { US } \$ \text {, } \\
\text { period } \\
\text { aver- } \\
\text { age) }\end{array}$ & $\begin{array}{l}\text { Money } \\
\text { and } \\
\text { quasi } \\
\text { money } \\
\left(\mathrm{M}_{2}\right) \\
\text { as \% of } \\
\text { GDP }\end{array}$ & $\begin{array}{c}\text { Inter- } \\
\text { est rate } \\
\text { spread }^{1} \\
(\%)\end{array}$ & $\begin{array}{c}\text { Total } \\
\text { re- } \\
\text { serves }^{2} \\
\text { (in- } \\
\text { cludes } \\
\text { gold, } \\
\text { current } \\
\text { US\$) }\end{array}$ & $\begin{array}{c}\text { GDP per } \\
\text { capita } \\
\text { (con- } \\
\text { stant } \\
2005 \\
\text { US\$) }\end{array}$ \\
\hline $2005-2009$ & $24 \cdot 7^{6}$ & $9^{38260.99}$ & 10.09 & 130.64 & 29.17 & 6.69 & $44 \cdot 48$ & 878.85 \\
\hline $2010-2014$ & 13.37 & $13895^{3.27}$ & $9 \cdot 7^{2}$ & 155.68 & 20.92 & 8.77 & 40.69 & $104,1.33$ \\
\hline 2015 & 13.37 & $2111.5^{3}$ & $9 \cdot 7^{2}$ & 192.44 & 20.92 & 8.77 & $4,0.69$ & 1041.33 \\
\hline
\end{tabular}

Source: Author's computation, from Central Bank of Nigeria Statistical Bulletin and World Bank World Development Indicators (WDI), 2015 and 2016-online version.

Figure 2.: Domestic credit, financial deepening and interest rate spread in Nigeria (\% of GDP)

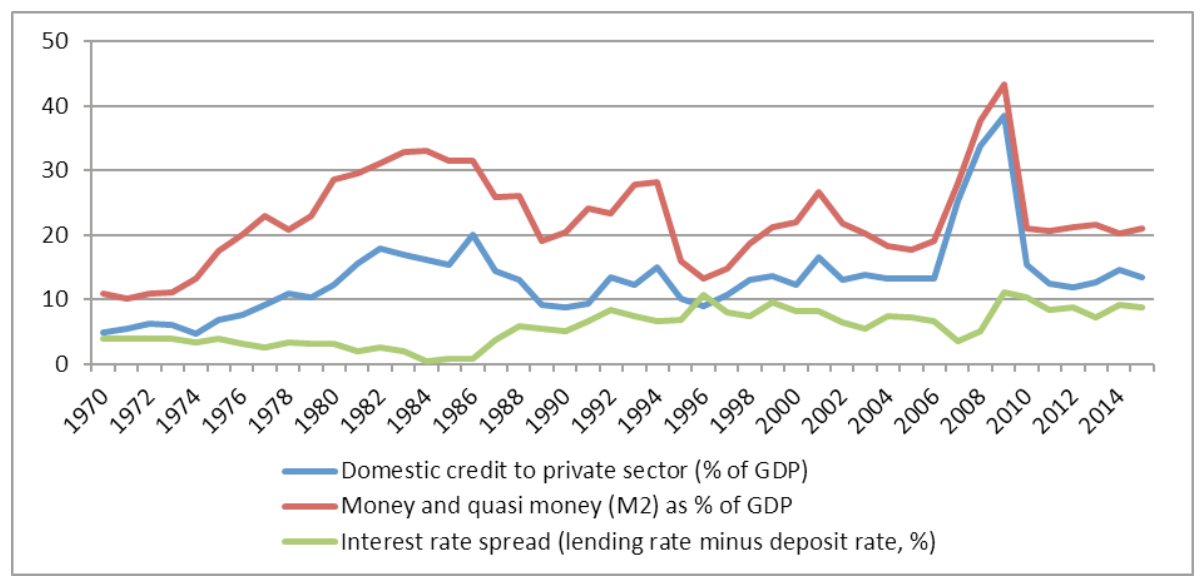

Source: Author, underlying data obtained from the WDI, 2015 and 2016 - online version.

To ascertain the threshold relationship between credits to private sector, interest rate spread and money supply $\left(\mathrm{M}_{2}\right)$ within the economy, Figure 2. provides a more direct view of the association. A perusal of the Figure does not reveal a unique relationship between credits to private sector, $\mathrm{M}_{2}$ and interest rate spread in Nigeria. Although, both credits to private sector and M2 exhibited a negative relationship with interest rate; high credits to private sector and $\mathrm{M}_{2}$ periods witnessed relatively low interest rate spread. In addition to this visual inspection, we further employed an econometric specification and estimation of the relationship.

1 Lending rate minus deposit rate.

2 In Billion. 


\section{LITERATURE REVIEW}

A number of studies have attempted to provide empirical evidence on the determinants of bank credit. These studies differ across areas, periods, methodological approaches and findings. Most recent studies reviewed are presented in Table 2. The literature on the determinants of bank credit has been conducted either from demand side or supply side. Consequently, some studies (Takas, 2010; and Everaert, 2015) investigated the strengths of each of these approaches in explaining bank credit. Moreover, the role of interest rate and economic growth as important determinants of bank credit is stressed among literature.

On the demand side analysis, Qayyum, (2002) combined uni-variate analysis, multivariate co-integration analysis with error correction mechanism (ECM) to examine the demand for bank lending by the private business sector in Pakistan during 1960-2000. His results showed that the output of business sector, as well as the rate of interest on bank advances, is important in determining the demand for bank credit. Similarly, Sharma and Gounder, (2012) investigated the determinants of bank credit in six Pacific Island Countries between 1982 and 2009 using generalized methods of moments (GMM). They found that lending rate and inflation rate have negative effect on credit growth while demand deposit, asset size and income have positive effect on credit growth. Moreover, Tan, (2012) employed net interest margin as a specific determinants of private credit growth in a baseline regression analysis for the case of Philippines and Asia using quarterly data from 2002 to 2010 . Income, reserve requirement and banking sector development have negative impact on net interest margin, whereas inflation, stock market development and government deficit exert positive effect on net interest margin. In the case of Germany, Ewert, (2000) employed panel data regression analysis to show that banks' rating is significant and positively related to the interest rate premium which is detrimental to bank lending performance.

On the supply side analysis, Imran and Nishat, (2013) adopting an autoregressive distributed lag model (ARDL) for the case of Pakistan, revealed that financial liabilities, domestic deposit, economic growth, exchange rate and M2 are significantly associated with bank credit in the long run while inflation and money market rate does not have any significant effect on bank credit. Also, their results indicated that financial health and liquidity are important determinants of loan in the short run with domestic deposit having no influence on bank credit. These findings appears to be consistent with that of Assefa, (2014) who investigated the determinants of growth in bank credit to the private sector in Ethiopia using ARDL and ECM. He found that domestic deposit, financial liabilities, real lending rate, M2, GDP and inflation rate have significant impact on bank credit in the long-run, though domestic deposit and GDP do not influence commercial bank credit. In a similar analysis of 38 emerging market economies during 2001-2010, Guo and Stepanyan, (2011) found that foreign 
borrowing, domestic deposit and economic growth were the major determinants of bank credit both at pre- and post-crisis.

Pertinent to the above, both the supply and demand factors have been identified to play important roles in determining bank credit. For instance, Everaert, et al., (2015) investigated the role of supply and demand in driving the credit cycle among the Central, Eastern, and South-eastern European countries between 2003 and 2012 using maximum likelihood framework. They reported that supply factors were more important than the demand side in explaining credit growth in the post-crisis. In contrast, Shijaku and Kalluci, (2013) who adopted vector error correction model for the case of Albania, stressed that banking, financial intermediation and financial liberalisation have positive effect on lending demand while lending rate and GDP have negative effect on lending demand. The earlier findings of Takas, (2010) for the case of 21 emerging market economies from 1995 to 2009 provided reconciliation through a panel regression framework. He submitted that both demand and supply factors contributed to the fall in cross border lending to these economies during the period, but the impact of supply was stronger.

In the case of Nigeria, Olokoyo, (2011) examined the determinants of commercial banks' lending behaviour in Nigeria during $1980-2005$. The ordinary least square (OLS) and VECM results showed that bank deposit has the greatest impact on lending behaviour. However, Akinleye, (2012) provided evidence that lending rate and saving-deposit ratio were the primary drivers of changes in the supply and demand for credit in the Nigerian banking sector. Alternatively, the results of the vector autoregressive model employed by Emecheta and Ibe, (2014) revealed a significant and positive relationship between bank credit and GDP. In an assessment of macroeconomic indicators and commercial banks' risk assets creation in Nigeria between 1981 and 2011. Asekome and Agbonkhese, (2014) indicated, in an OLS analysis, that capacity utilization and $\mathrm{M}_{2}$ have positive effect on risk asset while the impact of inflation, GDP and exchange rate is negative.

Existing studies have clearly shown inconclusive results on the determinants of bank credit as these drivers appear to vary among countries and regions. Supply-side literature has shown similar results, although with some level of agreement on the role of economic growth or income. Thus, there is need for further studies on the determinants of bank credit especially as it relates to supply factors. Furthermore, the supply side factors drive the availability of bank credit for investment purposes which in turn enhances economic growth. However, studies in this area are limited in Nigeria. To the best of our knowledge, the only related study is Olokoyo, (2011) whose results stressed the role of bank deposit, which may be a question of methodology. This present study attempts to fill these gaps and contribute to literature through an application of bound testing approach to the selected variables. 
Table 2.: Summary of studies on financial development-growth nexus

\begin{tabular}{|c|c|c|c|c|c|}
\hline \multirow[b]{2}{*}{$\mathbf{S} / \mathbf{N}$} & \multirow[b]{2}{*}{ Author } & \multirow{2}{*}{$\begin{array}{l}\text { Scope } \\
\text { (Period) }\end{array}$} & \multicolumn{2}{|c|}{ Methodology } & \multirow[b]{2}{*}{ Main findings } \\
\hline & & & Variables & $\begin{array}{l}\text { Estimation } \\
\text { techniques }\end{array}$ & \\
\hline 1 & $\begin{array}{r}\text { Qayyum, } \\
(2002)\end{array}$ & $\begin{array}{r}\text { Pakistan } \\
(1960- \\
2000)\end{array}$ & $\begin{array}{l}\text { DBP, LY,R } \\
\text { and INF }\end{array}$ & $\begin{array}{r}\text { Uni-variate } \\
\text { analysis, } \\
\text { multivariate } \\
\text { cointegration } \\
\text { analysis, and } \\
\text { EGM }\end{array}$ & $\begin{array}{l}\text { The output of business sector is an } \\
\text { important determinant of the demand } \\
\text { for bank credit. The rate of interest } \\
\text { on bank advances is an important } \\
\text { determinant of the demand of credit by } \\
\text { the business sector. }\end{array}$ \\
\hline 2 & $\begin{array}{r}\text { Imran and } \\
\text { Nishat, } \\
(2013)\end{array}$ & $\begin{array}{r}\text { Pakistan } \\
\left(1971^{-}\right. \\
2010)\end{array}$ & $\begin{array}{r}\text { CPI, FL, } \\
\text { DD, Y, ER, } \\
\text { MMR, M2 } \\
\text { and BC }\end{array}$ & ARDL & $\begin{array}{l}\text { FL, DD, Y, ER and M2 are significantly } \\
\text { associated with BC in the long run; INF } \\
\text { and MMR does not affect the BC; DD } \\
\text { does not influence BC in the short- } \\
\text { run; Financial health and liquidity are } \\
\text { also important determinants of loan }\end{array}$ \\
\hline 3 & $\begin{array}{r}\text { Sharma } \\
\text { and } \\
\text { Gounder, } \\
(2012)\end{array}$ & $\begin{array}{r}\text { Six Pacific } \\
\text { Island } \\
\text { Countries } \\
(1982- \\
2009)\end{array}$ & $\begin{array}{r}\text { LR, INF, } \\
\text { BC, BD, } \\
\text { BA, SM } \\
\text { and Y }\end{array}$ & GMM & $\begin{array}{r}\text { LR and INF have negative effect on } \\
\text { credit growth; DD and AZ have positive } \\
\text { effect on credit growth; Y also have } \\
\text { positive relationship with credit } \\
\text { growth }\end{array}$ \\
\hline 4 & $\begin{array}{r}\text { Assefa, } \\
(2014)\end{array}$ & $\begin{array}{r}\text { Ethiopia } \\
\left(197^{8-}\right. \\
2011)\end{array}$ & $\begin{array}{r}\mathrm{DD}, \mathrm{FL}, \mathrm{LR}, \\
\mathrm{M}_{2}, \mathrm{Y},\end{array}$ & $\begin{array}{r}\text { ARDLand } \\
\text { ECM }\end{array}$ & $\begin{array}{r}\text { DD, FL, LR, M2, Y, INF have } \\
\text { significant impact on BC in the long- } \\
\text { run; RR does not affect commercial } \\
\text { BC both in long and short-run; In the } \\
\text { short-run, DD and Y do not influence } \\
\text { commercial BC }\end{array}$ \\
\hline 5 & $\begin{array}{r}\text { Asekome } \\
\text { and Ag- } \\
\text { bonkhese, } \\
2014 \text { ) }\end{array}$ & $\begin{array}{r}\text { Nigeria } \\
(1981- \\
2011)\end{array}$ & $\begin{array}{r}\mathrm{Y}, \mathrm{M}_{2}, \mathrm{ER}, \\
\mathrm{LR}, \mathrm{CAU}, \\
\mathrm{INF} \text { and } \\
\mathrm{RA}\end{array}$ & OLS & $\begin{array}{r}\text { Y, INF and ER have negative effect } \\
\text { on RA while } \mathrm{CU} \text { and } \mathrm{M}_{2} \text { have positive } \\
\text { impact on RA }\end{array}$ \\
\hline 6 & $\begin{array}{r}\text { Shijaku } \\
\text { and } \\
\text { Kalluci, } \\
(2013)\end{array}$ & $\begin{array}{r}\text { Albania } \\
\left(2,001 Q_{1} \text { to }\right. \\
\left.2011 Q_{4}\right)\end{array}$ & $\begin{array}{r}\text { BC, REER, } \\
\text { GDB, LR, } \\
\text { Y, NW and } \\
\text { DD }\end{array}$ & VECM & $\begin{array}{r}\text { Banking, financial intermediation and } \\
\text { financial liberalisation have positive } \\
\text { effect on lending demand; LR and } \\
\text { GDB have negative effect on lending } \\
\text { demand }\end{array}$ \\
\hline 7 & $\begin{array}{r}\text { Guo and } \\
\text { Stepanyan } \\
(2011)\end{array}$ & $\begin{array}{r}38 \\
\text { emerging } \\
\text { market } \\
\text { economies } \\
\left(2001^{-}\right. \\
2010)\end{array}$ & $\begin{array}{r}\text { INF, Y, DR, } \\
\text { BC(Growth } \\
\text { rate) and } \\
\mathrm{M}_{2}\end{array}$ & $\begin{array}{r}\text { Regression } \\
\text { analysis }\end{array}$ & $\begin{array}{r}\mathrm{FB}, \mathrm{DD} \text { and } Y \text { were the major } \\
\text { determinants of BC both at pre- and } \\
\text { post-crisis }\end{array}$ \\
\hline 8 & $\begin{array}{r}\text { Akinleye } \\
(2012)\end{array}$ & $\begin{array}{c}\text { Nigeria } \\
((1986- \\
2007))\end{array}$ & $\begin{array}{l}\text { BC, LR, } \\
\text { SDR, ER, } \\
\text { LQR, NB } \\
\text { and LDR }\end{array}$ & $\begin{array}{r}\text { Descriptive } \\
\text { statistics }\end{array}$ & $\begin{array}{r}\text { LR and SDR were the primary drivers } \\
\text { behind changes in the supply and } \\
\text { demand for credit in the banking } \\
\text { sector }\end{array}$ \\
\hline 9 & $\begin{array}{r}\text { Emecheta } \\
\text { and Ibe, } \\
(2014)\end{array}$ & $\begin{array}{r}\text { Nigeria } \\
(1960- \\
2011)\end{array}$ & $\begin{array}{r}\mathrm{M}_{2}, \mathrm{Y} \text { and } \\
\mathrm{BC}\end{array}$ & VAR & $\begin{array}{r}\text { Significant and positive relationship } \\
\text { exist between } \mathrm{BC} \text { and } \mathrm{Y}\end{array}$ \\
\hline 10 & $\begin{array}{r}\text { Olokoyo, } \\
(2011)\end{array}$ & $\begin{array}{l}\text { Nigeria } \\
(1980- \\
2005)\end{array}$ & $\begin{array}{r}\mathrm{LA}, \mathrm{BD}, \mathrm{IP}, \\
\mathrm{LR}, \mathrm{RR} \text { and } \\
\mathrm{LQR}\end{array}$ & $\begin{array}{l}\text { OLS and } \\
\text { VECM }\end{array}$ & $\begin{array}{r}\text { BD has the greatest impact on lending } \\
\text { behavior }\end{array}$ \\
\hline
\end{tabular}




\begin{tabular}{|c|c|c|c|c|c|}
\hline \multirow[b]{2}{*}{$\mathbf{S} / \mathbf{N}$} & \multirow[b]{2}{*}{ Author } & \multirow{2}{*}{$\begin{array}{l}\text { Scope } \\
\text { (Period) }\end{array}$} & \multicolumn{2}{|c|}{ Methodology } & \multirow[b]{2}{*}{ Main findings } \\
\hline & & & Variables & $\begin{array}{l}\text { Estimation } \\
\text { techniques }\end{array}$ & \\
\hline 11 & $\begin{array}{l}\text { Takas, } \\
(2010)\end{array}$ & $\begin{array}{r}21 \\
\text { emerging } \\
\text { market } \\
\text { economies } \\
\left(1995^{-}\right. \\
2009)\end{array}$ & $\begin{array}{r}\mathrm{V}(\text { supply } \\
\text { side }) \text {, } \\
\mathrm{Y}(\text { demand } \\
\text { side) and } \\
\text { cross } \\
\text { border } \\
\text { lending }\end{array}$ & $\begin{array}{r}\text { Panel } \\
\text { regression } \\
\text { framework }\end{array}$ & $\begin{array}{l}\text { Both demand and supply factors } \\
\text { contributed to the fall in cross border } \\
\text { lending to these economies during the } \\
\text { period, but the impact of supply was } \\
\text { stronger }\end{array}$ \\
\hline 12 & $\begin{array}{c}\text { Everaert et } \\
\text { al., }(2015)\end{array}$ & $\begin{array}{r}\text { Central, } \\
\text { Eastern, } \\
\text { and South- } \\
\text { eastern } \\
\text { European } \\
\text { countries } \\
(2003- \\
2012)\end{array}$ & $\begin{array}{r}\text { LR, INF, } \\
\text { Y, M, UM, } \\
\text { NW, Debt } \\
\text { overhang, } \\
\text { DR etc }\end{array}$ & $\begin{array}{r}\text { Maximum } \\
\text { likelihood } \\
\text { method }\end{array}$ & $\begin{array}{l}\text { Supply factors was more important } \\
\text { than the demand side in explaining } \\
\text { credit growth in the post-crisis period }\end{array}$ \\
\hline 13 & $\begin{array}{r}\text { Tan, } \\
(2012)\end{array}$ & $\begin{array}{r}\text { Phillipines } \\
\text { and Asia } \\
\left(2002: Q_{1} \text { to }\right. \\
\text { 2010:Q4) }\end{array}$ & $\begin{array}{r}\text { Y, INF, } \\
\text { RR, GD, } \\
\text { DD, NIM, } \\
\text { IP, BC } \\
\text { (growth) } \\
\text { etc }\end{array}$ & $\begin{array}{r}\text { Baseline } \\
\text { regression } \\
\text { analysis }\end{array}$ & $\begin{array}{r}\mathrm{Y}, \mathrm{RR} \text { and banking sector development } \\
\text { have negative impact on net interest } \\
\text { margin, whereas INF, stock market } \\
\text { development and government deficit } \\
\text { have positive effect on net interest } \\
\text { margin }\end{array}$ \\
\hline 14 & $\begin{array}{l}\text { Ewert, } \\
(2000)\end{array}$ & $\begin{array}{r}\text { Germany } \\
\left(1992^{-}\right. \\
1998)\end{array}$ & $\begin{array}{r}\text { Rating, } \\
\text { sales, } \mathrm{R} \text {, } \\
\text { collateral } \\
\text { etc }\end{array}$ & $\begin{array}{r}\text { Panel data } \\
\text { regression } \\
\text { analysis }\end{array}$ & $\begin{array}{r}\text { The banks' rating is significant and } \\
\text { positively related to the interest rate } \\
\text { premium, and hence important to } \\
\text { bank lending policy }\end{array}$ \\
\hline
\end{tabular}

Note: ECM = Error Correction Model; BC = Bank Lending/Credit to the Private Business Sector; LY= Industrial output as proxy of output of business sector; $\mathrm{R}=$ Real rate of interest on bank advances; INF= Rate of inflation; $\mathrm{CPI}=$ Consumer price index; FL=foreign liabilities; $\mathrm{DD}=$ domestic deposits; $\mathrm{Y}=\mathrm{GDP} /$ economic growth; ER= exchange rate; $\mathrm{MMR}=$ money market rate; $\mathrm{M}_{2}=$ Broad money; $\mathrm{LR}=$ Lending rates; $\mathrm{AZ}=\mathrm{Asset}$ size; $\mathrm{BD}=\mathrm{Bank}$ deposit; BA=Bank asset; $\mathrm{SM}=$ Stock market; $\mathrm{GMM}=$ Generalised methods of moments; ARDL= Autoregressive distributed lag model; $\mathrm{CU}=$ Capacity utilisation RA=Risk asset; VECM= Vector error Correction Model, GDB = Government domestic borrowing, REER = Real effective exchange rate; NW= Net/Real wages; DR=Deposit rate; $\mathrm{SDR}=$ saving deposit ratio; $\mathrm{LQR}=$ liquidity ratio; $\mathrm{NB}=$ numbers of banks; $\mathrm{LDR}=$ loan to deposit ratio, Trade openness, GC= Government Consumption; SMT=Stock market turnover; VAR= vector autoregressive; $\mathrm{LA}=$ Loan advance; IP= Investment portfolio; V=Volatility of financial index; NIM= Net interest margin; $\mathrm{M}=$ Employment; UM = Unemployment rate; GD = government deficit; FB = Foreign borrowing.

\section{METHODOLOGY}

\subsection{Model specification}

In line with Vodova (2008), who summarizes several potential factors of demand and supply credit determinants that have been previously employed in the literature. However, Vodova (2008) himself did not utilized all of these determinants ${ }^{3}$.

3 He noted that not all the series are suitable for the analysis of Czech credit market because; some of the variables are either not available or does not make economic sense to use. Therefore, only a part of them was used for analysis (see next chapter). 
In this study 4 , the explanatory variables used are, GDP, Foreign Liabilities (measured as external Debt Outstanding), inflation, exchange rate, money supply, Interest rate spread and reserve requirement. This expressed below as:

$\mathrm{PSC}_{\mathrm{t}}=f\left(N F L_{t}, I N F_{t}, E X C H_{t}, M 2_{t}, I R S_{t}, R R_{t}, G D P_{t}\right)$

Where PSC = Domestic credit to private sector ( $\%$ of GDP), NFL = Nigeria's External Debt Outstanding $\left(\mathrm{N}^{\prime} \text { Billion }\right)^{5}, \mathrm{INF}=$ inflation, consumer prices (annual \%), $\mathrm{EXCH}=$ Official exchange rate (LCU per US\$, period average), $\mathrm{M}_{2}=$ Money and quasi money as \% of GDP, IRS = Interest rate spread (lending rate minus deposit rate, \%), $\mathrm{RR}=$ Total reserves (includes gold, current US\$) and GDP = GDP per capita (constant 2005 US\$).

Theoretically, it is expected that lending capacity (IRS) of financial institutions is positively associated with credit to private sector. Furthermore, both foreign liabilities (NFL) and Money supply (M2) are expected to positively impact credit to private sector because increases in loan from foreign financial institutions and money supply to domestic banks improve their assets as well as their liquidity, as a result they can lend more at domestic level, while general price level (INF) and exchange rate (EXCH) are expected to increase bank credit. However, while GDP is expected to have positive influence on the real volume of bank credit, the effect of reserve requirement (RR) is likely to be negative. Moreover, the positive sign for GDP is due to the fact that banks may form expectation about output growth and thus, if they expect a decline in output in the future, they can lower the credit supply in the present. Also, higher reserve requirement tends to reduce the ability of commercial banks to create credit.

\subsection{Estimation technique}

This study adopts the Autoregressive Distributed Lag (ARDL) model to empirically analyze the above functional form. According to Pesaran et al (2001), the ARDL co-integration technique (bound test), compared to other multivariate cointegration methods ${ }^{6}$, enables the co-integration relationship to be estimated by the ordinary least square (OLS) after determining the lag order of the model. Also, the model can accommodate regressors that are stationary at either levels I(O) or first difference I(1). In addition, the long run and short run parameters of the models can be simultaneously estimated (Pesaran et al, 2001).

The model is transformed into natural logarithmic to reduce heteroskedasticity and the ARDL estimable model is therefore, specified as:

4. While focusing only on the supply determinants factors.

5 Proxy for measure of Foreign liabilities.

6 Such as like Johansen (1998) and Johansen and Juselius (1990). 


$$
\begin{aligned}
\triangle_{L N P S C}= & \alpha_{0}+\alpha_{1} \text { LNPSC }_{t-i}+\alpha_{2} \text { LNNFL }_{t-i}+\alpha_{3} \text { LNINF }_{t-i}+\alpha_{4} \text { LNEXCH }_{t-i} \\
& +\alpha_{5} \text { LNM }_{t-i}+\alpha_{6} \text { LNIRS }_{t-i}+\alpha_{7} L N R R_{t-i}+\alpha_{8} L N G D P_{t-i} \\
& +\sum_{i=1}^{p} \alpha_{9 i} \Delta L N N F L_{t-i}+\sum_{i=1}^{p} \alpha_{10 i} \Delta L N I N F_{t-i}+\sum_{i=1}^{p} \alpha_{11 i} \Delta L N E X C H_{t-i} \\
& +\sum_{i=1}^{p} \alpha_{12 i} \Delta L N M 2_{t-i}+\sum_{i=1}^{p} \alpha_{13 i} \Delta L N I R S_{t-i}++\sum_{i=1}^{p} \alpha_{14 i} \Delta L N R R_{t-i} \\
& +\sum_{i=1}^{p} \alpha_{15 i} \Delta L N G D P_{t-i}+\mu_{t} \ldots \ldots \ldots \ldots \ldots \ldots \ldots \ldots \ldots \ldots \ldots \ldots \ldots \ldots \ldots \ldots \ldots \ldots \ldots \ldots \ldots \ldots \ldots \ldots \ldots
\end{aligned}
$$

All series are as defined before, $\mu_{t} \mu_{t}$ and LN are the white noise disturbance term and natural logarithmic respectively, while $\mathrm{C}$ is first differencing operator. The ARDL bounds test approach for the long-run relationship between credit to private sector and it's other determinants was estimated through the Wald test (F statistic), that imposed restrictions on the long-run obtained coefficients and other determinants variables to be equal to zero, that is, $H_{0}: \alpha_{1}=\alpha_{2}=\alpha_{3}=\alpha_{4}=\alpha_{5}=\alpha_{6}=\alpha_{7}=0$ for equation 4 .

According to Pesaran et, al. (2001), the explanatory variables are assumed to be integrated of order zero, or I(o) for values of the lower bound, while the upper bound values assumed that they are integrated of order one, or I(1). The decision rule is that if the computed Ward test F-statistic exceeds the upper bound value, I(1) then it can be concluded that credit to private sector and its determinants (under equation 2) are stable and co-integrated. Contrarily, if computed Ward test F-statistics falls below the lower bound value, I(o), the null hypothesis (no co-integration) cannot be rejected while decision is inconclusive if the computed Wald test F-statistics fall between the two bounds. The bounds specification of short run dynamics is then estimated using Error Correction Model (ECM) of the following form:

$$
\begin{aligned}
\Delta \text { LNPSC }_{t}= & \alpha_{0}+\sum_{i=1}^{p} \alpha_{1 i} \Delta L N P S C_{t-i}+\sum_{i=1}^{p} \alpha_{2 i} \Delta L N N F L_{t-i}+\sum_{i=1}^{p} \alpha_{3 i} \Delta L N I N F_{t-i} \\
& +\sum_{i=1}^{p} \alpha_{4 i} \Delta L N E X C H_{t-i}+\sum_{i=1}^{p} \alpha_{5 i} \Delta L N M 2_{t-i}+\sum_{i=1}^{p} \alpha_{6 i} \Delta L N I R S_{t-i} \\
& ++\sum_{i=1}^{p} \alpha_{7 i} \Delta L N R R_{t-i}+\sum_{i=1}^{p} \alpha_{8 i} \Delta L N G D P_{t-i}+\alpha_{9} E C T_{t-1} \\
& +\mu_{t} \ldots \ldots \ldots \ldots \ldots \ldots \ldots \ldots \ldots \ldots \ldots \ldots \ldots \ldots \ldots \ldots \ldots \ldots \ldots \ldots \ldots \ldots \ldots \ldots \ldots \ldots \ldots \ldots \ldots \ldots \ldots \ldots \ldots \ldots \ldots \ldots \ldots \ldots
\end{aligned}
$$

From equation 3, the one-time lagged residual term $\left(E C T_{t-1} E C T_{t-1}\right)$ depicts the disequilibrium in the long run relationship and $\alpha$ 's reflect the rate of changes of each variable in equation (3). Consequently, equation (3) also indicates credit to private sector influenced as explained by its past values and other shocks. Also, a number of post estimation diagnostic tests such as serial correlation test, heteroskedasticity and the Autoregressive Conditional Heteroskedasticity (ARCH) effect were 
applied. Thus, this representation can be used to examine both the short and longrun relationship between bank credit and its other determinants in Nigeria.

\subsection{Data sources}

Using annual time series data that covers the period from 1970-2015 to reexamine the link under study, all variables were sourced and computed accordingly from the Central Bank of Nigeria statistical Bulletin, 2014 and World Bank's Development Indicators (WDI, 2015 and 2016-online version).

\section{EMPIRICAL RESULTS AND DISCUSSIONS}

\subsection{Preliminary analysis: Descriptive, Correlation analysis and Unit root test}

Table 3. reports the descriptive statistics for variables employed in the analysis. The mean, standard deviation, skewness and kurtosis coefficients are shown with the Jarque-Bera statistics used to test the null hypothesis that all our variables are normally distributed. It is found that variability is highest for Nigeria foreign liabilities, reserve requirements and Gross Domestic Product, but lower for domestic credit to private sector, interest rate spread, money supply, inflation and exchange rate. Similarly, the series exchange rate, interest rate spread, money supply, Nigeria foreign liabilities (NFL) and reserve requirements (RR) are negatively skewed and leptokurtic and the Jarque-Bera statistics reject the null hypothesis of normality very strongly. Moreover, the Jarque-Bera statistics of other series accept the null hypothesis of normality.

Table 4. also showed the pair-wise correlation analysis of the variables used in the estimation. The results of the correlation analyses showed different significance level, signs, association and strength among variables. The correlation analysis is very important to determining the type of association that exist between each of the series used; which has implication for their inclusion in the same model. Thus, our variables are conformable for inclusion in the same model. In the same vein, Table 5 validate the assumption of critical values as suggested by Pesaran et al. (2001) that the variables are integrated of order I(O) or I(1).

Table 3.: Descriptive statistics of the variables

\begin{tabular}{|l|r|r|r|r|r|r|r|l|}
\hline & \multicolumn{1}{|c|}{ INF } & \multicolumn{1}{c|}{ EXCH } & \multicolumn{1}{c|}{ IRS } & \multicolumn{1}{c|}{ M2 } & NFL & PSC & GDP & RR \\
\hline Mean & 2.646 & 2.347 & 1.549 & 3.064 & 31.265 & 2.494 & 6.565 & 22.398 \\
Median & 2.521 & 2.968 & 1.730 & 3.052 & 32.386 & 2.563 & 6.555 & 22.419 \\
Maximum & 4.288 & 5.260 & 2.404 & 3.767 & 36.126 & 3.648 & 7.001 & 24.705 \\
Minimum & $\mathbf{1 . 2 4 1}$ & $-\mathbf{- 0 . 6 0 4}$ & $-\mathbf{- 1 . 1 5 0}$ & $\mathbf{2 . 3 0 7}$ & $\mathbf{2 5 . 8 8 8}$ & $\mathbf{1 . 5 4 7}$ & $\mathbf{6 . 2 0 3}$ & $\mathbf{1 9 . 2 2 5}$ \\
\hline
\end{tabular}




\begin{tabular}{|l|r|r|r|r|r|r|r|r|}
\hline & \multicolumn{1}{c|}{ INF } & EXCH & \multicolumn{1}{c|}{ IRS } & \multicolumn{1}{c|}{ M2 } & \multicolumn{1}{c|}{ NFL } & PSC & GDP & \multicolumn{1}{c|}{ RR } \\
\hline Std. Dev. & 0.710 & 2.315 & 0.728 & 0.331 & 3.470 & 0.431 & 0.240 & 1.479 \\
Skewness & 0.618 & -0.098 & -1.671 & -0.400 & -0.189 & 0.051 & 0.198 & -0.011 \\
Kurtosis & 2.820 & 1.330 & 6.271 & 2.977 & 1.488 & 3.845 & 1.656 & 2.152 \\
Jarque-Bera & 2.992 & 5.417 & 41.919 & 1.230 & 4.656 & 1.390 & 3.761 & 1.380 \\
Probability & 0.224 & 0.067 & 0.000 & 0.541 & 0.097 & 0.499 & 0.153 & 0.502 \\
Sum & 121.702 & 107.962 & 71.240 & 140.947 & 1438.174 & 114.742 & 302.000 & 1030.295 \\
Observations & 46 & 46 & 46 & 4.6 & 46 & 46 & 46 & 46 \\
\hline
\end{tabular}

Source: Author's computation.

Table 4.: Correlation analysis of the variables

\begin{tabular}{|l|r|r|r|r|r|r|r|l|}
\hline Variable(s) & \multicolumn{1}{c|}{ INF } & EXCH & \multicolumn{1}{c|}{ IRS } & \multicolumn{1}{c|}{ M2 } & NFL & PSC & GDP & RR \\
\hline CPI & 1.000 & & & & & & & \\
EXCH & -0.165 & 1.000 & & & & & & \\
IRS & $-0.05^{3}$ & $0.765^{*}$ & 1.000 & & & & & \\
M2 & 0.214 & 0.021 & $-0.25^{* * *}$ & 1.000 & & & & \\
NFL & 0.121 & $0.5^{3} 7^{*}$ & $0.474^{*}$ & 0.200 & 1.000 & & & \\
PSC & $-0.05^{8}$ & $0.405^{*}$ & 0.024 & $0.76^{*}$ & $0.459^{*}$ & 1.000 & & \\
GDP & -0.232 & 0.204 & -0.002 & -0.021 & $-0.42^{*}$ & 0.034 & 1.000 & \\
RR & -0.230 & $0.641^{*}$ & $0.444^{*}$ & 0.081 & $0.270^{* * *}$ & $0.292^{* * *}$ & $0.57^{*}$ & 1.000 \\
\hline
\end{tabular}

Source: Author's computation.

The time series properties of the variables employed in this study are evaluated by conducting Augmented Dickey-Fuller (ADF) and Philips-Perron (PP) unit root tests as suggested by both Dickey and Fuller (1979) and Phillips and Perron (1987). The results of the unit root tests are presented in Table 5 . Test for stationarity shows that all variables are integrated of order $\mathrm{I}(\mathrm{I})$ and thus, stationary after first differencing, except for inflation (INF) and credit to private sector (PSC) that are stationary at level.

Table 5.: Unit root tests results

\begin{tabular}{|c|c|c|c|c|}
\hline \multirow{2}{*}{\multicolumn{2}{|c|}{ Variable }} & \multicolumn{2}{|c|}{ Unit root tests } & \multirow{3}{*}{$\begin{array}{c}\begin{array}{c}\text { Order of } \\
\text { cointegration }\end{array} \\
\mathrm{I}(\mathrm{o})\end{array}$} \\
\hline & & \multirow{3}{*}{$\begin{array}{r}\mathrm{ADF} \\
-3.7^{815^{*}} \\
-6.9812^{*}\end{array}$} & \multirow{3}{*}{$\begin{array}{r}P P \\
-3.6244^{*} \\
-9.8284^{*}\end{array}$} & \\
\hline INF & Level & & & \\
\hline & ${ }^{1}{ }^{\text {st }}$ Difference & & & \\
\hline EXCH & Level & -0.2429 & $-0.34,32$ & $\mathrm{I}(\mathrm{I})$ \\
\hline & ${ }^{1}{ }^{\text {st }}$ Difference & $-5.3843^{*}$ & $-5.3873^{*}$ & \\
\hline IRS & Level & -2.0311 & -2.0766 & $\mathrm{I}(\mathrm{I})$ \\
\hline & ${ }_{1}{ }^{\text {st }}$ Difference & $-6.8378^{*}$ & $-7.2854 *$ & \\
\hline $\mathrm{M}_{2}$ & Level & $-3.5^{119^{* * *}}$ & -2.4980 & $\mathrm{I}(\mathrm{I})$ \\
\hline & $1^{\text {st }}$ Difference & $-5.4744^{*}$ & $-5.3980 *$ & \\
\hline NFL & Level & -2.4215 & -1.5530 & $\mathrm{I}(\mathrm{I})$ \\
\hline
\end{tabular}




\begin{tabular}{|c|c|c|c|c|}
\hline \multirow{2}{*}{\multicolumn{2}{|c|}{ Variable }} & \multicolumn{2}{|c|}{ Unit root tests } & \multirow{2}{*}{$\begin{array}{c}\text { Order of } \\
\text { cointegration }\end{array}$} \\
\hline & & \multirow{2}{*}{$\frac{\mathrm{ADF}}{-4.3560^{*}}$} & \multirow{2}{*}{$\begin{array}{r}\text { PP } \\
-4.1469^{*}\end{array}$} & \\
\hline & $1^{\text {st }}$ Difference & & & \\
\hline PSC & Level & $-2.6254^{* * * * *}$ & $-2.6268^{* * * *}$ & $\mathrm{I}(\mathrm{O})$ \\
\hline & $1^{\text {st }}$ Difference & $-5.3826^{*}$ & $-6.9510^{*}$ & \\
\hline GDP & Level & $-0.3 \circ 55$ & -0.6286 & $\mathrm{I}(\mathrm{I})$ \\
\hline & $1^{\text {st }}$ Difference & $-5 \cdot 7040^{*}$ & $-5 \cdot 7 \circ 39^{*}$ & \\
\hline RR & Level & $-1.925^{1}$ & -1.9813 & $\mathrm{I}(\mathrm{I})$ \\
\hline & $1^{\text {st }}$ Difference & $-5.64,03^{*}$ & $-5.9541^{*}$ & \\
\hline
\end{tabular}

Source: Author's computation.

Note: ADF and PP statistics with intercept, ${ }^{*},{ }^{* *}$ and $* * *$ indicates $1 \%, 5 \%$ and $10 \%$ significance level respectively, the optimal lag structure is determined by SIC.

\subsection{Analysis of regression results}

Proceeding to the co-integration test; the empirical result from the bounds test co-integration ${ }^{7}$ for bank credit supply determinants in Nigeria is presented in Table 6. The result revealed the computed F-Statistics for Wald test to be 18.69. The value exceeds both the upper bounds and lower bounds critical values for all level of significance. Therefore, the statistics test yields evidence of a long-run relationship between domestic credit to private sector, Nigeria foreign liabilities, inflation, exchange rate, money supply, interest rate spread, reserve requirements and gross domestic product at all levels of significance in Nigeria.

Table 6.: Bounds testing for Co-integration analysis

\begin{tabular}{|l|r|r|}
\hline \multicolumn{3}{|c|}{ Computed Wald f-statistic: 18.6988 (AIC Lags = 1) } \\
\hline Bounds level: & Lower I(o): & Upper I(1): \\
$1 \%$ critical bounds value & 2.96 & 4.26 \\
$5 \%$ critical bounds value & 2.32 & 3.50 \\
$10 \%$ critical bounds value & 2.03 & 3.13 \\
\hline
\end{tabular}

Source: Author's computation.

Notes: for the Wald F-Statistic; Asymptotic critical value bounds are obtained from Table G1 (iii) Case III: unrestricted intercept and no trend for $\mathrm{k}=\mathrm{\eta}$ (Pesaran, et. al 2001, pg. 3०o).

\subsubsection{Determinants of bank credit in Nigeria}

The short-run and long-run ARDL results for the determinants of bank credit are presented in Table 7 . Long-run results indicated that the price level exert negative and significant effect on bank credit as the elasticity of bank credit

7 According to Pesaran et, al. (2001), the decision rule is that if the computed F-statistic exceeds the upper bound value, I(1) then it can be concluded that the independent variable and its determinants are stable and co-integrated. Contrarily, if computed F-statistic falls below the lower bound value, I(o), the null hypothesis (no co-integration) cannot be rejected. 
with respect to price level is -0.12. However, the coefficients of exchange rate, money supply, net foreign liabilities and real GDP are positive and statistically significant. The results show that $1.0 \%$ increase in exchange rate or money supply led to about $0.07 \%$ or $0.71 \%$ rise respectively in bank credit. Also, a similar percentage rise in net foreign liability or real GDP increased bank credit by about $0.08 \%$ or $0.91 \%$ respectively. The results further, reveal that interest rate spread and reserve requirement does not have significant impact on bank credit in the long-run.

In the short-run, the coefficients of inflation and reserve requirement are negative and significant. Particularly, 1.0\% increase in inflation or reserve requirement reduced bank credit by about $0.07 \%$ or $0.17 \%$ respectively. Conversely, the impact of money supply and net foreign liabilities on bank credit is positive and significant. Thus, the elasticity of bank credit with respect to money supply and net foreign liabilities is about 1.0 and 0.05 respectively. The effect of exchange rate, interest rate spread and real GDP on bank credit is insignificant.

Table 7.: Parsimonious Long-run and Short-run ARDL-ECM results, Dependent variable is PSC

\begin{tabular}{|c|c|c|}
\hline Variable & Long-run & Short-run \\
\hline LOGCPI & $-0.1225(-2.2527)^{* *}$ & $-0.0684(-2.0851)^{* *}$ \\
\hline LOGEXCH & $0.0712\left(1.955^{1}\right)^{* * *}$ & $-0.079^{3}\left(-1.077^{8}\right)$ \\
\hline LOGIRS & $-0.147^{8}(-1.5415)$ & $0.0086(0.1689)$ \\
\hline $\mathrm{LOGM}_{2}$ & $0.7093(3.4,045)^{*}$ & $0.9790(8.0261)^{*}$ \\
\hline LOGNFL & $0.0814(3.0690)^{*}$ & $0.0454(2.9904)^{*}$ \\
\hline LOGRGDP & $0.9063(2.3850)^{* *}$ & $-0.1112(-0.3566)$ \\
\hline LOGRR & $-0.1029(-1.6105)$ & $-0.1660(-4.2030) *$ \\
\hline $\operatorname{ECM}(-1)$ & & $-0.55^{8} 5(-4.4720)^{*}$ \\
\hline $\mathrm{G}$ & $-5.4216(-2.24,38)^{* *}$ & \\
\hline R-SQUARE & \multicolumn{2}{|c|}{0.9523} \\
\hline AdJ. R-SQUARE & \multicolumn{2}{|c|}{0.9322} \\
\hline F-STATISTICS & \multicolumn{2}{|c|}{$47.6080^{*}$} \\
\hline AIC & \multicolumn{2}{|c|}{-1.3719} \\
\hline SIC & \multicolumn{2}{|c|}{-0.8099} \\
\hline D-WATSON & \multicolumn{2}{|c|}{2.1254} \\
\hline $\begin{array}{l}\text { Breusch-Godfrey serial } \\
\text { correlation LM test }\end{array}$ & \multicolumn{2}{|c|}{$0.2282(2)$} \\
\hline ARCH test & \multicolumn{2}{|c|}{$0.85 \circ 5(2)$} \\
\hline Breusch-Pagan-Godfrey & \multicolumn{2}{|c|}{$0.7231(2)$} \\
\hline Ramsey RESET test & \multicolumn{2}{|c|}{2.1433} \\
\hline
\end{tabular}

Source: Author's estimation from E-views 9. Note: *,** and ${ }^{* * * *}$ denote the level of significance at $1 \%$, $5 \%$ and $10 \%$ respectively, while values in parenthesis are the t-statistics. Also, F-statistics of BreuschGodfrey Serial Correlation LM Test, ARCH Test, White Heteroskedasticity test andRamsey RESET testwith lag 1. 
The coefficient of the error correction term (ECM) indicates that $56 \%$ deviation from the long-run equilibrium level of bank credit to the private sector is corrected for annually. Moreover, the diagnostic tests confirm the correctness of the estimated model. The Breusch-Godfrey LM test statistics rejected the existence of serial correlation, while the ARCH test and Breusch-Pagan-Godfrey confirms that the residuals are homoscedastic. Also, the Ramsey RESET test suggests that the specified functional form is adequate.

The significant negative coefficient of inflation implies that increase in general price level has decreasing effect on bank credit to the private sector both in the short and long-run. In Nigeria, inflation has continued to rise over the last three to four decades. This rising price level may suggest high inflation rate in the economy especially when such changes is persistent which is an indication of economic instability and rising cost of production. This economic phenomenon is usually a disincentive for commercial banks to lend to businesses for investment purposes. Further, the estimates indicate that money supply and net foreign liabilities exert increasing effect on bank credit to private sector both in the short and long-run. Increase in money supply raise the ability of commercial banks to increase bank loans for investment. Similarly, the easier it is for Nigerian banks to get loans from foreign financial institutions, the higher their level of assets and liquidity, hence bank credit. The findings in respect of inflation and money supply are consistent with those of Imram and Nishat (2013) for the case of Pakistan while the findings with respect to foreign liabilities support those of Assefa (2014) for the case of Ethiopia.

The effect of real income (real GDP) and exchange rate on bank credit is only in the long-run while that of reserve requirement is only in the short-run. The positive coefficient of real GDP indicates that as the economy grows and real income rises, banks become optimistic about business outcomes and are more willing to grant credit to firms. Also, the positive effect of exchange rate reveals that the value of private credit in terms of domestic currency appears to rise relative to foreign currency credit. These findings are also in line with Imram and Nishat (2013). Contrary to Assefa (2014) where insignificant effect of reserve requirement on bank credit was reported, the findings of this present paper suggest that as reserve requirement increases, the ability of banks to create money through bank credit is reduced significantly in the short-run. Moreover, interest rate spread appears to have negligible impact on bank credit as its contribution may be infinitesimal both in the short and long-run.

As a check of robustness of the results, the analyses on determinants of bank credit supply are further conducted for quarterly series of the same variables covering the same period. The results of the analysis, which are reported in the appendix, are similar to those obtained for the annual series. However, the results of the quarterly analysis showed that the effect of inflation is in the long run while that of exchange rate and real GDP appears both in the short and long-run. 


\section{CONCLUSION AND POLICY RECOMMENDATIONS}

This study queries the long-run and short-run supply side factors influencing bank credit in Nigeria using annual data for the period of 1970-2015 by applying the ARDL-ECM-Bounds test proposed by Pesaran et al. (2001). Results showed evidence of a long-run relationship among domestic credit to private sector, real GDP, foreign liabilities, inflation, exchange rate, money supply, interest rate spread and reserve requirement at all levels of significance for Nigeria.

Specifically, findings reveal that exchange rate, money supply, net foreign liabilities and real GDP have positive long-run impact on bank credit to private sector in Nigeria, whereas the effect of general price level is negative. In the short run, the effect of money supply, net foreign liabilities and reserve requirement on bank credit to private sector is positive with only inflation exerting negative influence. The effect of interest rate spread is insignificant. Thus, the health of the financial system including bank liquidity is important for bank credit determination. A strong economic condition increased aggregate demand and improves business atmosphere which reduces the probability of moral hazard and adverse selection and creates incentives for banks to give credit in the process. This increases the level of investment across sectors, hence increasing the per capita income and savings will in turn raises bank credit in the process. Policy makers are required to implement policies that stabilize the financial system and boost per capita income in order to promote a sustained and stable growth of bank credit to private sector in Nigeria. 


\section{REFERENCES}

Afzal, A., Mirza N., "The determinants of interest rate spread in Pakistan commercial banking sector". Lahore School of Economics CREB Working Paper, No, (2010):01-10

Akinleye G. T. Ojenike J. O. and Afolabi A. A. "Demand for, and Supply of Credit in Nigerian Banking Sector," Research Journal of Finance and Accounting, Vol 3, No 8, (2012)

Ali, K., Akhtar, M.F., Ahmed, H.Z. "Bank specific macroeconomic indicators of profitability: empirical evidence from commercial banks in Pakistan". International Journal of Business and Social Science 2 (6), (2011): $235^{-246}$

Asekome M. O. and Agbonkhese A. O. "Macroeconomic Indicators and Commercial Banks' Risk Assets Creation in Nigeria," European Scientific Journal vol.10, No.13, (2014)

Assefa M. "Determinants of Growth in Bank Credit to the Private Sector in Ethiopia: A Supply Side Approach," Research Journal of Finance and Accounting, Vol.5, No.17, (2014)

Awan, A.G., "Comparison of Islamic and conventional banking in Pakistan". Proceeding 2nd CBRC, Lahore, (2009)

Blanchard O. "Macroeconomics". Forth Edition, Pearson Education International, (2005)

Dickey D. A. and Fuller, W. A. "Distribution of the Estimators for the Autoregressive Time Series with a Unit Root," Journal of the American Statistical Association, Vol. 79, No. 386, (1979): 355-367

Emecheta B. C. and Ibe R. C. "Impact of Bank Credit on Economic Growth in Nigeria: Application of Reduced Vector Autoregressive (VAR) Technique," European Journal of Accounting Auditing and Finance Research, Vol.2, No.9, (2014): 11-21

Engle R. and Granger, C. "Co-integration and Error Correction Representation: Estimation and Testing," Econometrica, Vol. 55, No. 2, (1987): 251-276

Everaert G., Che N., Geng N., Gruss B., Impavido G., Lu Y., Saborowski C., Vandenbussche J., and Zeng L. "Does Supply or Demand Drive the Credit Cycle? Evidence from Central, Eastern, and Southeastern Europe," International Monetary Fund Working paper, 15/15, (2015)

Ewert R., Schenk G. and Szczesny A.”Determinants of Bank Lending Performance in Germany," Schmalenbach Business Review, Vol.52, (2000): 344 - 362,

Guo K. and Stepanyan V. "Determinants of Bank Credit in Emerging Market Economies," International Monetary Fund Working paper 11/51, (2011)

Imran K. and Nishat M. "Determinants of Bank Credit in Pakistan: A supply Side Approach," Economic Modelling 35, (2013): 384-390

Johansen S, and Juselius, K. "Maximum Likelihood Estimation and Inference on Co-integration-with Application to the Demand for Money" Oxford Bulletin of Economics and Statistics, Vol. 52, No. 2, (1990): $169-210$

Johansen, S. "Statistical analysis of cointegration vectors". Journal of Economic Dynamics and Control 12, (1998): $231-254$

Khawaja M. I. and Din M." Determinants of interest spread in Pakistan". The Pakistan Development Review, $46: 2(2007): 129^{-143}$

Olokoyo F. O. "Determinants of Commercial Banks' Lending Behaviour in Nigeria," International Journal of Financial Research Vol. 2, No. 2, (2011): 61-72 
Pesaran M.H, Shin Y, and Smith R.J. "Bounds Testing Approaches to the Analysis of Level Relationships." Journal of Applied Econometrics; 16, (2001): 289-326

Phillips P. C. B. and Perron, P. "Testing for a Unit Root in Time Series Regression" Biometrika, Vol. 75, No. 2, $(1987): 335-346$

Qayyum A. "Demand for Bank Lending by the Private Business Sector in Pakistan," The Pakistan Development Review 41 (2), (2002): 149-159

Sharma P. and Gounder N. "Determinants of Bank Credit in Small Open Economies: The Case of Six Pacific Island Countries," Griffith Business School Discussion Paper, No. 2012-13, (2012): ISSN 1836-8123

Shijaku G. and Kalluci I. "Determinants of Bank Credit to the Private Sector: The Case of Albania," Bank of Albania Discussion Paper, o9 (48), (2013)

Takáts E. "Was it credit supply? Cross-border bank lending to emerging market economies during the financial crisis," BIS Quarterly Review, (2010): 49-56

Tan T. B. P. "Determinants of Credit Growth and Interest Margins in the Philippines and Asia," International Monetary Fund Workingpaper, 12/123, (2012)

The World Bank. World Development Indicators, Washington, DG; (2016)

The World Bank. World Development Indicators, Washington, DC; (2015)

Vodova, P. Creditmarket and prediction of its future development in the Czech Republic Available at www. https://core.ac.uk/download/pdf/73o1536.pdf. (2008) 


\section{APPENDIX: QUARTERLY SERIES RESULTS}

Table A: Parsimonious Long-run and Short-run ARDL-ECM results, Dependent variable is PSC

\begin{tabular}{|c|c|c|}
\hline Variable & Long-run & Short-run \\
\hline LOGCPI & $-0.0780(-1.1175)$ & $-0.0561(-3.9099) *$ \\
\hline LOGEXCH & $0.0721(1.7195)^{* * * *}$ & $0.0090(1.6640)^{* * * *}$ \\
\hline LOGIRS & $-0.1334(-1.2720)$ & $-0.0167(-1.3994)$ \\
\hline $\mathrm{LOGM}_{2}$ & $0.7823(3.8124)^{*}$ & $1.0586(20.3301)^{*}$ \\
\hline LOGNFL & $0.0695(2.4776)^{* * *}$ & $0.0323(3.7350)^{*}$ \\
\hline LOGRGDP & $0.8822(2.2677)^{* * *}$ & $0.1103(2.1560)^{* * *}$ \\
\hline LOGRR & $-0.0980(-1.554 .2)$ & $-0.1423\left(-8.555^{1}\right)^{*}$ \\
\hline $\operatorname{ECM}(-1)$ & & $-0.125^{\circ}\left(-3.557^{6}\right)^{*}$ \\
\hline $\mathrm{C}$ & $-5.390121(-2.1100)^{* * *}$ & \\
\hline R-SQUARE & \multicolumn{2}{|c|}{0.9809} \\
\hline AdJ. R-SQUARE & \multicolumn{2}{|c|}{0.9796} \\
\hline F-STATISTICS & \multicolumn{2}{|c|}{$729.0920^{*}$} \\
\hline $\mathrm{AIC}$ & \multicolumn{2}{|c|}{-2.7060} \\
\hline $\mathrm{SIC}$ & \multicolumn{2}{|c|}{$-2.47^{80}$} \\
\hline D-WATSON & \multicolumn{2}{|c|}{1.9804} \\
\hline $\begin{array}{l}\text { Breusch-Godfrey serial } \\
\text { correlation LM test }\end{array}$ & \multicolumn{2}{|c|}{0.0113} \\
\hline ARCH test & \multicolumn{2}{|c|}{$1.75^{83}$} \\
\hline Breusch-Pagan-Godfrey & \multicolumn{2}{|c|}{0.8950} \\
\hline Ramsey RESET test & \multicolumn{2}{|c|}{0.6159} \\
\hline
\end{tabular}

Source: Author's estimation from E-views 9. Note: ${ }^{*}, * *$ and ${ }^{* * * *}$ denote the level of significance at $1 \%$, $5 \%$ and $10 \%$ respectively, while values in parenthesis are the $\mathrm{t}$-statistics. Also, F-statistics of BreuschGodfrey Serial Correlation LM Test, ARCH Test, White Heteroskedasticity test and Ramsey RESET test with lag 1. 